\title{
LIKHET FOR LOVEN
}

Av PROFESSOR RAGNHILD HENNUM

Equality before the law involves two principles: formal equality and material equality. Formal equality requires a consistent and objective application of the law in regard to the individual. Material equality requires equal distribution of rights and benefits. This article examines the extent to which Norwegian law provides both formal and material equality.

I dette innlegget skal jeg belyse tre problemstillinger knyttet til likhet for loven. For det første spørsmålet om hvor vi finner kravet om likhet for loven? For det andre spørsmålet om hva kravet om likhet for loven innebærer? Og for det tredje spørsmålet om vi har likhet for loven?

\section{Hvor finner vi kravet om likhet for loven?}

Det er enighet om at likhet for loven er et grunnleggende rettsstatsprinsipp. I norsk rett kommer imidlertid ikke prinsippet til uttrykk i en generell bestemmelse. Vi har for eksempel ingen regel om likebehandling i Grunnloven. Dog er det slik at Grunnloven inneholder en bestemmelse om at alle har krav på erstatning ved ekspropriasjon (§ 105) og en bestemmelse om alminnelig verneplikt (§ 109). Begge disse bestemmelsene er utslag av likhetstanken, men det er kun eksempler på situasjoner der det skal likebehandles ikke generelle regler om likebehandling. I ekstreme tilfeller kan det også være aktuelt at Høyesterett tisidesetter en diskriminerende lov på grunn av ulovfestede ${ }^{1}$ prinsipper om likebehandling, dette går jeg ikke nærmere inn på her.

Dersom vi ser på våre internasjonale forpliktelser finner vi kravet om likhet for loven nedfelt flere steder. Kravet er blant annet nedfelt i FNs Verdenserklæring art. 7, der første setning lyder slik: "All are equal before the law and are entitled without any discrimination to equal protection of the law." I FNs konvensjonen om sivile og poitiske rettigheter fra 1966 finner vi en likende formulering i art. 26, der første setning lyder slik: "All persons are equal before the law and are entitled without any discrimination to the equal protection of the law."

Videre gir artikkel 26 anvisning på et forbud mot diskriminering uansett rase, farge, kjønn, språk, religion, politisk eller annen oppfatning, nasjonal eller sosial opprinnelse, eiendom, fødsel eller annen status. Bestemmelsen i artikkel 26 krever altså likebehandling generelt, den retter seg ikke kun mot likebehandling på konvensjonsrettighetenes område (jfr. formuleringen "alle er like for loven"). En

\footnotetext{
* Title in English: Equality Before the Law. Original in Norwegian.
} 
ser at artikkel 26 angir tre ${ }^{2}$ prinsipper: Prinsippet om likhet for loven, prinsippet om lik beskyttelse av loven, og forbud mot diskriminering.

Det første prinsippet: Prinsippet om likhet for loven innebærer et krav om formell likhet. Det retter seg i første rekke mot domstolene - og krever lik behandling av like tilfeller.

Det andre prinsippet: Kravet om lik beskyttelse av loven innebærer etter ordlyden ikke nødvendigvis noe mer enn at personer formelt skal behandles likt. På grunnlag av teori og praksis er det imidlertid slått fast ${ }^{3}$ at det også følger et krav om materiell likhet. Statene er forpliktet til å iverksette visse positive tiltak for å fremme reell likhet (for eksempel har Menneskerettighetskomiteen uttalt dette $i$ forbindelse med likebehandling av kvinner).

Det tredje prinsippet: Forbudet mot diskriminering innebærer et krav om at lovgivningen skal forby forskjellsbehandling og gi effektiv beskyttelse mot forskjellsbehandling.

I Den europeiske menneskerettighetskonvensjon er ikke prinsippet om likhet for loven like uttrykkelig uttrykt, men art. 14 inneholder et direkte forbud mot diskriminering. Denne bestemmelsen gjelder imidlertid kun likebehandling i forhold til de rettigheter som er beskyttet av EMK, den inneholder ikke noe generelt krav om likebehandling. Det er imidlertid vedtatt en 12. tileggsprotokoll til EMK (den er ennå ikke i kraft). Den 12. tilleggsprotokollen slår fast et likhetsprinsipp likende det vi finner i SP. art. 26.

\section{Hva er likhet for loven?}

Alf Ross skrev ${ }^{4}$ om likhetskravet at det var : "... blottet for enhver selvstendig og håndgripelig mening" (min oversettelse). Om begrepet er full så innholdsløst som Ross fremholder kan etter mitt skjønn diskuteres. Uansett er det enkelt å være enig $i$ at begrepet bør presiserer for å gi god mening.

Utgangspunktet for en diskusjon av likhet for loven må være et krav om at alle har lik beskyttelse av loven. Altså at lovene ikke er direkte diskriminerende, for eksempel lover som gir menn rett til å eie eiendom, mens kvinner ikke har tilsvarende rett. Selv om denne type direkte diskriminerende lovgivning ligger noe tilbake i tid i de Nordiske land, er det fremdeles mange land som har direkte diskriminerende ${ }^{5}$ lover, dette gjelder også europeiske land.

Videre må vi skille mellom formell og materiell likhet (rettferdighet). Kravet om formell likhet retter seg i første rekke mot dommerne og er et krav om at loven skal anvendes likt uavhengig av hvem det gjelder, altså et krav om at like tilfeller behandles likt. Alf Ross ${ }^{6}$ forbeholdt begrepet likhet eller rettferdighet til slik formell likhet.

Slik begrepet brukes for eksempel i SP art. 26 innebærer kravet om likhet for loven noe mer enn kun formell likhet, det innebærer også et krav om materiell 
likhet (rettferdighet). Noe som medfører et krav om at loven skal sikre lik fordeling av rettigheter og andre goder. I denne sammenheng skal jeg se på begge disse sidene av kravet om likhet for loven.

\section{Har vi likhet for loven?}

Jeg starter med å se på kravet om formell likhet - behandles like saker likt? Her nøyer jeg meg med å referere undersøkelser av norske forhold. Etter oppslag i media om geografiske forskjeller i straffutmålingen undersøkte ${ }^{7}$ jeg selv på oppdrag fra Justisdepartementet straffutmålingen i noen saker i første innstans. Undersøkelsen innebar en gjennomgang av 150 tilfeldig valgte dommer fra førsteinstans fra året 2000. Undersøkelsens hovedkonklusjon er at straffutmålingen er (forholdsvis) lik i sammenliknbare saker. Denne undersøkelsen er imidlertid liten, kun 150 dommer ble gjennomgått. For å trekke mer sikre konklusjoner om straffutmålingen bør et større utvalg saker undersøkes.

En annen undersøkelse ${ }^{8}$ som belyser likhet for loven ble gjennomført av Senter mot etnisk diskriminering i år 2000. I undersøkelsen ble 248 advokater spurt om erfaringer med etnisk diskriminering i rettsvesenet. Undersøkelsen viste blant annet at ca. 130 advokater mener at en parts etniske opprinnelse eller hudfarge kan ha betydning for sakens behandling i rettsapparatet. Av advokatene var det ca. 100 som hadde opplevd at dommeren opptrådte annerledes når en av partene har minoritetsbakgrunn enn hva som var tilfelle når alle de involverte var etnisk norske. En noe mindre andel advokater (82) hadde opplevd rettens avgjørelse som annerledes når klienten hadde minoritetsbakgrunn. Det var 100 advokater som hadde opplevd kvalitet på tolkning som et rettssikkerhetsproblem. Selv om det er mange metodiske problemer knyttet til undersøkelser av denne typen, er den en indikasjon på at det kan forekomme etnisk diskriminering i rettsvesenet.

Statistisk sentralbyrå har også gjennomført undersøkelser ${ }^{9}$ som finner at siktede med innvandrerbakgrunn frifinnes oftere enn siktede totalt, dessuten får innvandrere oftere saken henlagt. Dette tyder på at de utsettes for større kontroll (de siktes) fra politiets siden enn etnisk norske. Er det likhet for loven?

I forhold til formell likhet for loven har vi altså undersøkelser som trekker i retning av at det ikke er formell likhet og undersøkelser som trekker i motsatt retning. Bildet er altså litt uklart og det er behov for ytterligere forskning for å fastslå om og eventuelt i hvilket omfang personer/grupper ikke behandles likt. Dog har vi undersøkelser som viser at personer med innvandrerbakgrunn utsetter for langt sterkere kontroll fra politiets side enn etnisk norske.

Dersom vi går videre og ser på den materielle likheten blir bildet mindre tvetydig. Kravet om materiell likhet medfører et krav om at loven skal sikre lik fordeling av rettigheter og andre goder. Jeg skal belyse dette spørsmålet med å referere til to nyere 
studentarbeider som begge undersøker prøveløslatelse. I en undersøkelse av søknader om prøveløslatelser fant kriminolog Ellen Sevaldrud (hovedfag i kriminologi 2005) at personer med godt sosialt nettverk som kunne skaffe bolig og arbeid ved løslatelse oftere ble prøveløslatt ved 2/3 tid enn personer som ikke hadde noen utenfor fengselet som kunne hjelpe dem med bolig/arbeid. Dette medførte at personer med et dårlig sosialt nettverk og få ressurser i praksis sonet mer (lenger) av fengselsstraffen enn personer med et godt sosialt nettverk. Et tilsvarende funn gjorde Ingrid Bakken i sin masteroppgave i rettsvitenskap. Bakken undersøkte prøving ${ }^{10}$ av vilkårene for fortsatt forvaring. Hun fant at et argument for å nekte prøveløslatelse fra forvaring var mangel på arbeid, bolig og sosialt nettverk. Dette medførte at personer som hadde et godt sosialt nettverk, med muligheter for bolig og arbeid og dermed en stabil tilværelse ved prøveløslatelse kom bedre ut av sakene enn personer som manglet dette nettverket. Ved å referere disse undersøkelsene mener jeg ikke å antyde at fengselsmyndighetene (Sevaldruds saker) eller tingretten (Bakkens saker) anvendte loven feil eller at de diskriminerte personer med dårlig sosialt nettverk og få ressurser. Tvert $\mathrm{i}$ mot ble reglene anvendt riktig. Det at man har jobb, bolig og et godt sosialt nettverk er viktige forutsetninger for at en person som løslates på prøve skal holde seg borte fra ny kriminalitet (som litt enkelt sagt er suksesskriteriet ved prøveløslatelse). Det er altså helt relevant å ta hensynt til dette ved vurdering av prøveløslatelse.

Det er altså slik at selv om reglene anvendes helt korrekt og like tilfeller behandles helt likt så soner de mest ressurssvake lengre enn personer med ressurser til å skaffe seg arbeid/bolig osv. I dette tilfellet er det altså slik at rettsreglene ikke omfordelte goder eller skapte større materiell likhet. Tvert i mot forsterket rettsreglene de eksisterende forskjellene. Resultatet av disse undersøkelsene er gode eksempler på hvor vanskelig det er å skape materiell likhet gjennom rettsreglene. Kanskje har vi for store forhåpninger til rettsreglenes endringskraft når vi forventer at reglene skal skape materiell likhet. Trolig må det mye mer inngripende sosiale reformer til (enn lovendringer) for å skape lik fordeling av rettigheter og andre goder mellom kvinner og menn, barn og voksne, rike og fattige, svarte og hvite osv. Dette betyr selvfølgelig ikke at lovgivningen ikke skal forsøke å skape materiell likhet, poenget er at lovgivningen alene neppe er tilstrekkelig.

\section{Litteratur:}

Aall, Jørgen (2004): Rettsstat og menneskerettigheter. Oslo: Fagbokforlaget. Bakken, Ingrid (2007): Fortsatt forvaring. En undersøkelse av praksis ved Asker og Bcerum tingrett. Masteroppgave i rettsvitenskap - Universitetet i Oslo, 2007. Gundersen,Frants, Ulla Haslund, Arnt Even Hustad og Reid Jone Stene (2002): Innvandrere og nordmenn som offer og gjerningsmenn. SSB Rapport 2000/18. Haslund, Ulla (1995): 'Innvandrere og kriminalitet”. I: Samfunnsspeilet 1995, nr. 2. 
Haslund, Ulla og Kåre Vassenden (1997): ’Kriminalitet”. I: Vassenden, Kåre (red.): Innvandrere i Norge. Hvem er de, hva gjør de og hvordan lever de? Statistiske analyser 20, Statistisk sentralbyrå.

Hennum, Ragnhild (2002): Domstolenes utmåling av straff - en undersøkelse av rettspraksis. Justis og politidepartementet. Rapport 2002.

Høgberg, Alf Petter (2006): "Om kritikken av fenomenet reelle hensyn, begrepet reelle hensyn og termen reelle hensyn." I Fauchald, Jakhelln og Syse (red): dog Fred er ej det Bedste... festskrift til Carl August Fleicher Oslo: Universitetsforlaget.

NORGE- en rettsstat for alle? (2000) Senter mot etnisk diskriminering og Organisasjonen mot offentlig diskriminering.

Ross, Alf (1953): Om ret og retfardighed : en indførelse $i$ den analytiske retsfilosofi. København : Nyt Nordisk Forlag

Sevaldrud, Ellen Sofie (2005): Prøveløslatelsen : en undersøkelse om vilkårene for løslatelse på $2 / 3$ tid. Hovedfagsoppgave i kriminologi - Universitetet i Oslo, 2005.

\section{Noter:}

Se Aall 2004 s. 32-33 for en nærmere drøftelse.

Se mer om dette i NOU 2005: 8. Likeverd og tilgjengelighet Rettslig vern mot diskriminering på grunnlag av nedsatt funksjonsevne. Bedret tilgjengelighet for alle.

3 Se Aall 2004, s. 65 med videre henvisninger.

4 Ross 1953, s. 371.

5 På hjemmesidene til en kvinneorganisasjon som heter Equality now finner man oppdaterte lister over land som har direkte diskriminerende lover (se: www.equalitynow.org).

6 Ross 1953, s. 356. Se Høgberg 2006 for en nærmere drøftelse av dette.

7 Hennum 2002. Hele rapporten kan lastes ned gratis fra Justisdepartementets hjemmeside. http://www.regjeringen.no/nb/dep/jd/dok/rapporter_planer/rapporter/2002/Domstolenes-utmaling-av-straff---en-unde.html?id=461042

8 Rapporten "Norge - en rettsstat for alle" kan lastes ned gratis her: www.smed.no/rapporter/NORGE_en_rettsstat_for_alle.doc

$9 \quad$ Se Haslund 1995, Haslund og Vassenden 1997 og Gundersen, Haslund, Hustad og Stene 2000 (den siste rapporten kan lastes ned gratis på denne nettadressen: www.ssb.no/emner/03/05/ rapp_200018/rapp_200018.pdf)

10 Forvaring er en straff som i prinsippet er tidsubestemt. Det er (ting)retten som prøver vilkårene for prøveløslatelse.

\section{Adresse:}

Institutt for offentlig rett

Universitetet i Oslo

Postboks 6707

$\mathrm{N}-0130$ Oslo

Telefon +4722859483

E-mail: r.h.hennum@jus.uio.no 